\title{
Potential of Barringtonia Racemosa (L.) Dichloromethane extract on Streptozotocin (STZ) - Induced Type 2 Diabetic Rats
}

\author{
Isaac John Umaru ${ }^{1,2 *}$, Hauwa A Umaru ${ }^{3}$ and Kerenhappuch I Umaru ${ }^{4}$ \\ ${ }^{1}$ Faculty of Resource Science and Technology, University of Malaysia Sarawak, Malaysia \\ ${ }^{2}$ Department of Biochemistry, Federal University, Nigeria \\ ${ }^{3}$ Department of Biochemistry, Moddibo Adama University of Technology, Nigeria \\ ${ }^{4}$ Department of biochemistry, University of Maiduguri, Nigeria
}

Submission: September 28, 2018; Published: January 25, 2019

*Corresponding author: Isaac John Umaru, Faculty of Resource Science and Technology, University of Malaysia Sarawak, Kota Samarahan, Malaysia

\begin{abstract}
Objective: Type 2 diabetes mellitus is a heterogeneous group of metabolic disorders characterized by persistent hyperglycaemia. The aim of this research work is to gather scientific information about the possibility to utilize the dichloromethane leaf extract of Barringtonia racemosa as an agent of antidiabetic drug.

Material and Methods: The Crude extract was obtained through serial extract of five solvents, Hexane, dichloromethane, ethyl acetate, chloroform and methanol while the Assessment of type 2 anti-diabetes was conducted on Streptozotocin (STZ) -induced diabetic albino rats and the data were analysed through one-way ANOVA software. Histopathological studies of the pancreas and kidney were made to get evidence of the $\beta$-cell performance and the renal tissue respectively.
\end{abstract}

Results: The streptozotocin (STZ) induced diabetic rats treated with the Dichloromethane extract experienced an antidiabetic effect and the histopathologic observations showed increasing of the granulated $\beta$-cell at $\mathrm{p}<0.0001$ ) and no renal tissue damage in the tested rats.

Conclusion: The result of this study revealed that the dichloromethane crude extract of Barringtonia racemosa could be utilized as an agent source of type 2 anti-diabetes

Keywords: Barringtonia racemose; Dichloromethane; Alloxan; Diabetic; Rats

Abbreviations: STZ: Streptozotocin; T2DM: Type II Diabetes Mellitus; WHO: World Health Organization

\section{Introduction}

Type II diabetes mellitus (T2DM) is a fast-growing epidemic affecting people globally. Furthermore, multiple complications and co-occurring with a primary disease are associated with T2 diabetes. Lifestyle modifications along with pharmacotherapy and patient education are the mainstay of therapy for patients afflicted with T2DM. Western medications are frequently associated with severe adverse drug reactions and high costs of treatment. However, herbal medications have long been used in the treatment and prevention of T2DM in traditional medicine which was presumed to avert this treat of health around the globe. This disorder is a chronic metabolic menace characterized by absolute or relative deficiencies in insulin secretion or insulin action associated with chronic hyperglycaemia and disturbances of carbohydrate, lipid and protein metabolism [1].
The disease is of three types recognized by the World Health Organization (WHO) such as (i) type 1 diabetes (insulin-dependent) (ii) type 2 diabetes (non-insulin-dependent) and (iii) gestational diabetes. The $\beta$-cells in the pancreas are the key players in this disorder called glycaemic homeostasis. The glucotoxicity, lipotoxicity, inflammatory mediators and incretion were reported to modulate function and survival of $\beta$-cell [2]. Besides, oxidative stress is thought to be a major risk factor on the onset and progression of diabetes [3]. Both type-1 and type-2 diabetes are associated with increased formation of free radicals and decreased antioxidant potential [4]. Thus, T2DM accounts for over $90 \%$ of cases globally [5-7]. According to the World Health Organization (WHO), in 2011, approximately 364 million people globally suffer from diabetes (DM), with projections that DM-related deaths will double from 2005 to 2030 [8]. 


\section{Current Research in Diabetes \& Obesity Journal}

Diabetes being a common disease in the developed and developing countries. According to a WHO report in 2011, approximately 360 million people globally suffer from diabetes. The epidemic is more pronounced in developing countries such as Malaysia, Nigeria respectively because of their feeding habits. As per reports of the WHO, 32 million people of Malaysia had diabetes. The Malaysians would have a total number of 2.48 million diabetics compared to 0.94 million in 2000 that is about $164 \%$ increase. it is expected that more people in Malaysia will be affected by diabetes in the near future [9].

In the study of this diabetes diseases there are several animal models available to test for the mechanisms of diabetic complications, most of the studies on diabetic in animal models are largely restricted to type 1 diabetic (T1D) conditions $[10,11]$. In this context streptozotocin (STZ) [12-14], or alloxan-induced diabetic models [15-17] are extensively used to study the diabetic among scientist and both these models mimic the T1D in humans. It was reported that oxidative stress appears to be a major factor in the Table 1: Ethno Pharmacological uses and activity of Barringtonia racemose.

\begin{tabular}{|c|c|c|}
\hline Part of Plant Use & Treatment & Reference \\
\hline $\begin{array}{l}\text { Leaves } \\
\text { Stem-bark } \\
\text { Roots } \\
\text { Seeds } \\
\text { Fruits }\end{array}$ & $\begin{array}{l}\text { High blood pressure, itching, chicken pox itch, rheumatism } \\
\text { febrifuge. Fish poison, insecticide, skin disease, Deobstruent, } \\
\text { Relief in stomach ache Tumors, fish poison, colic, febrifuge, } \\
\text { vermufuge Poison wild pig, cough, asthma, diarrhea, eczema. } \\
\text { Hemicrania, ophthalmia, cough, asthma, diarrhea }\end{array}$ & $\begin{array}{l}\text { Kabir et al. [34], Osman et al. [35] } 2015 \mathrm{Lim} \\
\text { [36]. Isaac et al. [37], Giesen et al. [38], Man- } \\
\text { junah [39]. Jayaweera et al. [40]. Thomas et } \\
\text { al. [41], Manjunah et al. [39], Jayaweera et al. } \\
\text { [40], Giesen et al. [38], Nadkami [42] }\end{array}$ \\
\hline $\begin{array}{l}\text { Part of plant (Antioxidant) } \\
\text { Leaves } \\
\text { Leaves, stem-bark } \\
\text { Fruits } \\
\end{array}$ & $\begin{array}{l}\text { Secondary Metabolites Terpenoid, Flavonoid, Phenolic and } \\
\text { phenolic acid Phenolic acid }\end{array}$ & $\begin{array}{l}\text { Behbahani et al. [43], } \\
\quad \text { Kong et al. [44] } \\
\text { Sulaiman \& Ooni, [45]. }\end{array}$ \\
\hline $\begin{array}{l}\text { (Antibacterial)Leaves } \\
\text { Stem-bark } \\
\text { Roots }\end{array}$ & $\begin{array}{l}\text { Mycobacterium smegmatic Staphylococcus aureus, Staphylo- } \\
\text { coccus epidermidis, Eschericia coli, Shigella dysentriae, Vibrio } \\
\text { cholerae, Proteus sp. Bacillus cereus, Salmonella typhy }\end{array}$ & $\begin{array}{l}\text { Mmushi et al. [46] } \\
\text { Saha et al. [47] } \\
\text { Khan et al. [33]. }\end{array}$ \\
\hline $\begin{array}{l}\text { (Antifungal) } \\
\text { Leaves } \\
\text { Leaves, stem-bark }\end{array}$ & $\begin{array}{l}\text { Antimycobacterial Mycobacterium smegmatic Antifungus } \\
\text { Fusarium sp., Tricoderma koningii, Penicillium sp., Ganoderma } \\
\text { tropicum, Ganoderma lucidum, Aspergillus sp., Rhizopus sp. } \\
\text { Saprolegnia sp. }\end{array}$ & $\begin{array}{l}\text { Mmushi et al. [45]. } \\
\text { Hussin et al. [48]. }\end{array}$ \\
\hline (Anti-inflammatory) Fruits & $\begin{array}{l}\text { Carrageenan-induced paw oedema, Formalin-induced paw } \\
\text { oedema in albino rats. Carrageenan-induced acute inflamma- } \\
\text { tion in rats }\end{array}$ & Sikha et al. [49]. Patil et al. [50]. \\
\hline $\begin{array}{l}\text { ( } \alpha \text {-glucosidase inhibitor }) \\
\text { Seed } \\
\text { Fruits }\end{array}$ & $\begin{array}{l}\text { Yeast and intestinal Glucosidase inhibition Glucosidase inhibi- } \\
\text { tion Saccharomyces cerevisiae }\end{array}$ & $\begin{array}{l}\text { Gowri et al. [51]. } \\
\text { Sulaiman \& Ooi [45]. } \\
\text { Ponnapalli et al. [52]. }\end{array}$ \\
\hline $\begin{array}{l}\text { (Analgesic) Stem-bark } \\
\text { Fruits }\end{array}$ & $\begin{array}{l}\text { Albino male rats, steroid. Acetic acid-induced writhing re- } \\
\text { sponse }\end{array}$ & $\begin{array}{l}\text { Deraniyagala et al. [53] } \\
\text { Sikha et al. [50]. }\end{array}$ \\
\hline $\begin{array}{l}\text { (Cytotoxicity) Leaves, Stem-bark, } \\
\text { Roots }\end{array}$ & $\begin{array}{l}\text { Preliminary bioactive substances for Cancer cells } \\
\text { proliferation. }\end{array}$ & Isaac et al. [54] \\
\hline
\end{tabular}

Therefore, the choice of Barringtonia racemosa an evergreen mangrove plant, belonging to the family Lecythidaceae to cutely the menace of Diabetic disease is an option. The stem-bark and leaves have been traditionally used for anticancer, analgesic, antibacterial, anticolic and antifungal activities this motivated us to study the antidiabetic potential of this plant extract (Table 1) [2833]. development of other diseases in T1D, along with the activation of polyol pathway and non-enzymatic glycation $[12,13,18]$.

Thus streptozotocin (STZ) induced rat model is one of the most frequently used for T2D-like models which mimics human diabetes [19-22]. Previous studies on this model were found to have characteristics of pancreatic beta-cell destruction followed by beta-cell regeneration and glucose intolerance $[23,24]$. Subsequently, other authors confirmed these findings and showed that STZ treated rats in adulthood display the typical characteristics of T2D $[25,26]$. This animal model is mainly used to screen hypoglycaemic or antidiabetic agents $[16,17,27]$, and also for hypolipidemic and oxidative stress related studies [17]. However, no studies attempted to use this model for investigating the Assessment of Type 2 Anti-Diabetes of Barringtonia racemosa (L.) Dichloromethane extract in streptozotocin (STZ) - Induced Diabetic Rats. Therefore, in the present study we evaluated STZ model for development of an agent for T2D.

\section{Material and Methods}

\section{Materials}

Chemicals, drug and kit: All of the analytical grade chemicals, drug and the kit were procured commercially. The Streptozotocin (STZ) (Medical Resource SDN BHD Kuching, Sarawak) and metformin hydrochloride $\left(\mathrm{C}_{4} \mathrm{H}_{11} \mathrm{~N}_{5}\right)$ was decided as a positive control of the antidiabetic drug. The tested-diabetic rats were 


\section{Current Research in Diabetes \& Obesity Journal}

induced by the Streptozotocin (STZ) and was operated to measure the blood glucose level of the tested rats. All other chemicals were of analytical grade and were obtained from local companies.

\section{Experimental design}

Albino rats were obtained from the National Center for Laboratory Animal Sciences, unimas, were injected intraperitoneal with $90 \mathrm{mg} / \mathrm{kg}$ body weight STZ dissolved in $0.1 \mathrm{M}$ citrate buffer, pH $4.5(n=42)$. Control $(n=6)$ received normal diet. The rats were maintained on a normal diet in individual cages.

\section{Animal care}

Animal care and protocols were in accordance with and approved by the Institutional Animal Ethics Committee (IAEC). Animals were housed in individual cages in a temperature and humidity-controlled room.

\section{Sample collection}

The Leaves of Barringtonia racemosa was collected from Kampong Sarawak Malaysia by the river bank and Meranak at Meranak river bank in Kota-Samarahan Sarawak. Identification of the species was made by Prof Dr. Fasihuddin Bin Badruddin Ahmad and Prof Dr zaini B Assim. The samples were air-dried, cut into pieces and ground prior to analysis. It was then deposited into the polymer laboratory at Department of Chemistry, Faculty of Resource Science and Technology, UNIMAS.

\section{Preparation of sample extracts}

The collected Barringtonia racemosa were cut into thin slices and then air dried under shade for seven days. The dried leaves $(2 \mathrm{~kg})$ were ground with an electric blender and sieved with 40 $\mathrm{mm}$ mesh sieve to get a fine powder. The powder was stored in a dark bottle at room temperature until use.

\section{Extraction method}

The leaves of Barringtonia racemosa was extracted by the conventional solvent extraction method as described by Fasihuddin et al. [55]. This was achieved by soaking the ground powdered leaves in non-polar, medium polar and polar solvents in the order of increasing polarity. A total of $2 \mathrm{~kg}$ of the dried and ground Leaves of Barringtonia racemosa was extracted using cold soaking method with hexane $\left(\mathrm{C}_{6} \mathrm{H}_{14}\right)$. The samples were soaked in the hexane with the ratio of 1:3 in a 5 litres Erlenmeyer flasks at room temperature for 72 hours. The resulting hexane solution was then filtered using Histopathological study

Table 2: Effect of Barringtonia racemosa Dichloromethane extracts on Mean Streptozotocin (STZ) of type 2 Diabetic Rats.

\begin{tabular}{|c|c|c|c|c|c|}
\hline \multicolumn{6}{|c|}{ (Mean \pm SD mg/dl) Blood glucose level pre-treatment (Days) } \\
\hline & Treatment Groups & Dose mg/kg & Before Experiment & 3 Pre-Treatment & 7 pre-Treatments \\
\hline 1 & Normal & $0.25 \mathrm{ml}$ & $131.3 \pm 11.3$ & $132.5 \pm 6.41$ & $132.6 \pm 6.43$ \\
\hline 2 & Negative & $90 \mathrm{mg} / \mathrm{kg} / \mathrm{bwt}$ & $414.3 \pm 13.5$ & $414.5 \pm 5.32$ & $415.7 \pm 5.41$ \\
\hline 3 & Positive & $65 \mathrm{mg} / \mathrm{kg} / \mathrm{bwt}$ & $428.4 \pm 4.5$ & $428.5 \pm 45.5$ & $428.5 \pm 3.62$ \\
\hline 4 & Extracts & $100 \mathrm{mg} / \mathrm{kg} / \mathrm{bwt}$ & $415.3 \pm 12.3$ & $417 \pm 5.35$ & $418.7 \pm 52.42$ \\
\hline 5 & Extracts & $200 \mathrm{mg} / \mathrm{kg} / \mathrm{bwt}$ & $435.6 \pm 13.5$ & $437.7 \pm 7.7$ & $438.5 \pm 6.71$ \\
\hline 6 & Extracts & $300 \mathrm{mg} / \mathrm{kg} / \mathrm{bwt}$ & $425.3 \pm 2.8$ & $427.3 \pm 5.9$ & $435.9 \pm 7.62$ \\
\hline
\end{tabular}

filter paper and the residue was re-extracted with fresh hexane for another 72 hours and filtered. All the extracts were combined and concentrated using the rotary evaporator of model Heidolph Laborota 4000 efficient, under reduced pressure to obtain the hexane crude extract. The residues were then re-extracted using the same procedure with dichloromethane $\left(\mathrm{CH}_{2} \mathrm{CLl}_{2}\right)$, then ethyl acetate $\left(\mathrm{C}_{2} \mathrm{H}_{5} \mathrm{COOH}\right)$, chloroform $\left(\mathrm{CHCl}_{3}\right)$, and methanol $(\mathrm{MeOH})$ to obtain various extract of sample of dichloromethane, ethyl acetate, chloroform and methanol crude extracts, respectively.

\section{DPPH assay}

The DPPH (2,2-diphenyl-1-picrylhydrazyl, $\mathrm{C}_{18} \mathrm{H}_{12} \mathrm{~N}_{5} \mathrm{O}_{6}$ ) as reported by [37] of the leaves extract of Barringtonia racemosa was applied to evaluate the antioxidant activity to be $\mathrm{IC}_{50}=45.75$ which gives a base line potential of the activity of the extract against type 2 diabetic.

\section{In vivo experiment}

The healthy albino rats (150-200 g body weight) were conditioned in a cage for a week. After a week adaptation, the rats were separated into eight groups by setting: The Normal, negative and positive group. The remain five groups are the extract (dose) group of 100, 200, 300, 400, and 500mg/kg/bwt. Individual rat in each group was collected its blood on the 7th day and marked as a pre-treatment blood. The diabetic rat was generated by giving out the diabetic rat, all rats were given orally: The aqueous metformin hydrochloride of $65 \mathrm{mg} / \mathrm{kg} / \mathrm{bwt}$ in Positive control group, the aqueous tested extract of $100,200,300,400$ and $500 \mathrm{mg} / \mathrm{kg} /$ bwt in the extract's treatment group respectively every day after

Later on, this point, the individual rat in each group was collected its blood. The blood was noticeable as the blood obtained after treatment. One day later, a rat in each group was selected to be sacrificed for histopathological observation on the kidney and pancreas organs. The difference of blood glucose level was stated as an antidiabetic effect. 


\section{Current Research in Diabetes \& Obesity Journal}

\begin{tabular}{|l|l|c|c|c|}
\hline 7 & Extracts & $400 \mathrm{mg} / \mathrm{kg} / \mathrm{bwt}$ & $457.6 \pm 6$. & $457.9 \pm 1.3$ \\
\hline 8 & Extracts & $500 \mathrm{mg} / \mathrm{kg} / \mathrm{bwt}$ & $418.6 \pm 32.5$ & $433.4 \pm 3.5$ \\
\hline
\end{tabular}

Value with superscripts $c$ with a group along the row is significantly $(P<0.05)$ higher than zero hours' blood glucose value with superscript $d$ within the group along the row are significantly $(\mathrm{P}<0.05)$ lower than zero hours' blood glucose value. While value with superscript * between groups along the column is significantly $(P<0.05)$ lower than blood glucose value in the diabetic control group.

Table 3: Effect of Barringtonia racemosa dichloromethane extracts on blood glucose level of Streptozotocin (STZ)-induced diabetic Rats.

\begin{tabular}{|c|c|c|c|c|c|c|c|c|}
\hline \multicolumn{9}{|c|}{ (Mean \pm SD mg/dl) Blood Glucose Level Post Treatment (Days) } \\
\hline & Treatment groups & Dose $\mathbf{m g} / \mathbf{k g} / \mathbf{b w t}$ & $\mathbf{0}$ & $\mathbf{3}$ & $\mathbf{7}$ & $\mathbf{1 4}$ & $\mathbf{2 1}$ & $\mathbf{2 8}$ \\
\hline 1 & Normal & $0.25 \mathrm{ml}$ & $132.6 \pm 6.43$ & $123.5 \pm 6.4^{*}$ & $122.6 \pm 6.4^{*}$ & $119.4 \pm 7.3^{*}$ & $120.0 \pm 5.5^{*}$ & $121.2 \pm 4.4 \mathrm{~b}^{*}$ \\
\hline 2 & Negative & $90 \mathrm{mg} / \mathrm{kg} / \mathrm{bwt}$ & $415.7 \pm 5.14$ & $388.5 \pm 5.3 \mathrm{a}^{*}$ & $411.7 \pm 5.4 \mathrm{a}^{*}$ & $417.7 \pm 5.9 \mathrm{a}$ & $427.2 \pm 8.6 \mathrm{~b}^{*}$ & $456.7 \pm 6.4 \mathrm{a}$ \\
\hline 3 & Positive & $65 \mathrm{mg} / \mathrm{kg} / \mathrm{bwt}$ & $428.5 \pm 3.62$ & $243.5 \pm 45.5$ & $222.5 \pm 3.6^{*}$ & $199.3 \pm 3.4 \mathrm{c}^{*}$ & $176.3 \pm 6.4$ & $166.6 \pm 5.2 \mathrm{a}^{*}$ \\
\hline 4 & Extracts & 100 & $418.7 \pm 52.42$ & $326.4 \pm 5.3^{*}$ & $298.7 \pm 52.4 \mathrm{a}^{*}$ & $232.78 \pm 15.3$ & $224.6 \pm 11.8$ & $217.7 \pm 9.7$ \\
\hline 5 & Extracts & 200 & $438.5 \pm 6.71$ & $327.7 \pm 7.7 \mathrm{c}^{*}$ & $311.5 \pm 6.7 \mathrm{a}^{*}$ & $255.5 \pm 4.4$ & $233.3 \pm 4.5$ & $115.2 \pm 8.5 \mathrm{~b}$ \\
\hline 6 & Extracts & 300 & $435.9 \pm 7.62$ & $287.3 \pm 5.9 \mathrm{c}^{*}$ & $235.9 \pm 7.6 \mathrm{a}^{*}$ & $218.7 \pm 7.4$ & $205.8 \pm 3.7$ & $176.9 \pm 6.4^{*}$ \\
\hline 7 & Extracts & 400 & $458.2 \pm 4.31$ & $277.9 \pm 1.3$ & $201.8 \pm 4.3$ & $195.3 \pm 7.3^{*}$ & $182.4 \pm 2.2$ & $152.8 \pm 3.6^{*}$ \\
\hline 8 & Extracts & 500 & $434.6 \pm 3.29$ & $233.4 \pm 3.5$ & $190.8 \pm 3.9$ & $175.3 \pm 2.7^{*}$ & $153.4 \pm 5.5^{*}$ & $95.5 \pm 5.8^{*}$ \\
\hline
\end{tabular}

Value with superscripts a with a group along the row is significantly $(\mathrm{P}<0.05)$ higher than zero hours' blood glucose value with superscript b within the group along the row are significantly $(\mathrm{P}<0.05)$ lower than zero hours' blood glucose value. While value with superscript * between groups along the column is significantly $(\mathrm{P}<0.05)$ lower than blood glucose value in the diabetic control group.

The kidney and pancreas organs were submerged in Neutral matoxylin Eosin (HE) and studied under Olympus binocular reBuffered Formalin for a week and then histopathological investi- $\quad$ search microscope (Tables 2-4 \& Figures 1 \& 2). gations were performed [57]. The slices were stained with Hae-
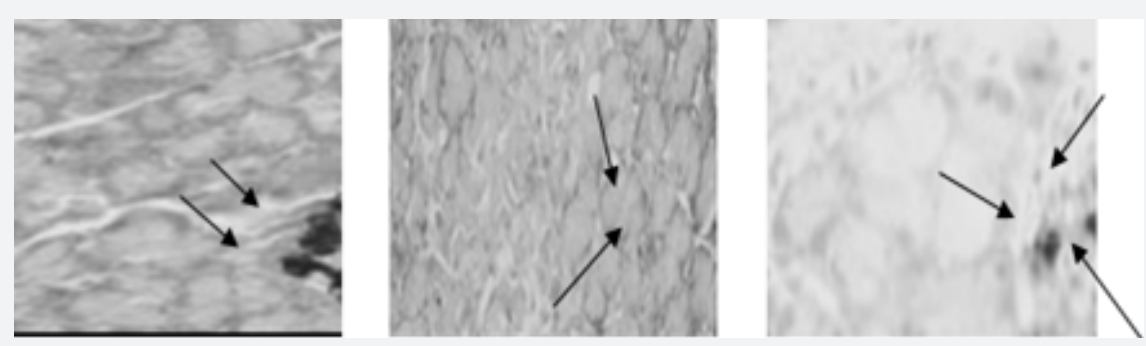

Figure 1: (b) Histopathological observation of pancreatic $\mathrm{H}$-cell as indicated by the black arrow in the normal rat, while (a). Streptozotocin (STZ)induced pancreatic H-cell and (c). Diabetic rat + Barringtonia racemosa Dichloromethane extract with a dose of $400 \mathrm{mg} / \mathrm{kg} / \mathrm{bwt}$.

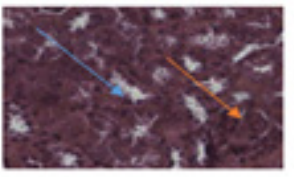

(a)

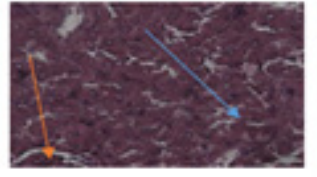

(b)

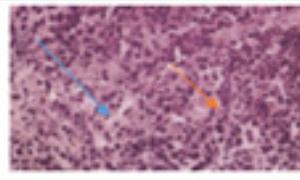

(c)

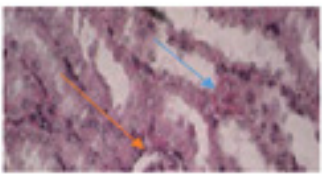

(d)

Figure 2: Histopathological performance of kidney in the normal rat (a), Metformin hydrochloride (b), diabetic rat + Dichloromethane extract with dose in $100 \mathrm{mg} \mathrm{kg}-1$ b.wt. (c), diabetic rat + bound flavonoids extract with a dose of $500 \mathrm{mg} / \mathrm{kg} / \mathrm{bwt}$. (d). Pink arrow: Proximal convoluted tubule, Blue arrow: Glomerulus.

\section{Results}

The in vivo experiment on the Streptozotocin (STZ)-induced T2-diabetic rats shown decreasing the blood glucose level along with increasing dose of the extract as shown in Table 3, The study of the proximate renal tubule cell scores in the rat's kidney at various treatment indicated renal damage within the normal range and as well as increase in the $\beta$-cell granulation Tables $4 \& 5$. 


\section{Current Research in Diabetes \& Obesity Journal}

Table 4: Proximate renal tubule cell score in the rats at various treatments.

\begin{tabular}{|c|c|c|c|}
\hline Group & Dose (mg/kg/bwt) & Proximate Convolution Tubule Score (Mean \pm SD) & \\
\hline 1 & Normal & - & - \\
\hline 2 & Negative & $90 \mathrm{mg} / \mathrm{kg} / \mathrm{bwt}$ & $0.23 \pm 1.05$ \\
\hline 3 & Positive & $65 \mathrm{mg} / \mathrm{kg} / \mathrm{bwt}$ & $0.45 \pm 0.63$ \\
\hline 4 & extract & 100 & $0.35 \pm 0.60$ \\
\hline 5 & extract & 200 & $0.32 \pm 0.63$ \\
\hline 6 & Extract & 300 & $0.34 \pm 0.61$ \\
\hline 7 & Extract & 400 & $0.33 \pm 0.59$ \\
\hline 8 & Extract & 500 & $0.32 \pm 0.62$ \\
\hline
\end{tabular}

$P=(0.001)$ in proximal renal tubule cell count among the treatments based on one-way ANOVA analysis. Significant statistical difference

Table 5: Granulation of pancreatic $\beta$-cell at various treatments.

\begin{tabular}{|c|c|c|c|}
\hline & Group & Dose $(\mathbf{m g} / \mathbf{k g} / \mathbf{b w t})$ & Pancreatic $\boldsymbol{\beta}$-cell (Mean \pm SD) \\
\hline 1 & Normal & - & $463.20 \pm 10.73$ \\
\hline 2 & Negative & $90 \mathrm{mg} / \mathrm{kg} / \mathrm{bwt}$ & $394.04 \pm 15.35$ \\
\hline 3 & Positive & $65 \mathrm{mg} / \mathrm{kg} / \mathrm{bwt}$ & $382.01 \pm 10.66$ \\
\hline 4 & extract & 100 & $397.23 \pm 11.45$ \\
\hline 5 & extract & 200 & $432.11 \pm 13.54$ \\
\hline 6 & Extract & 300 & $486.00 \pm 23.33$ \\
\hline 7 & Extract & 400 & $520.31 \pm 14.64$ \\
\hline 8 & Extract & 500 & \\
\hline
\end{tabular}

$\mathrm{P}<(0.001)$ in Pancreatic cell count among the treatment is based on one-way ANOVA analysis. Different letters indicated statistical difference

\section{Discussion}

Type 2 Diabetes is a metabolic disorder which has genetic and lifestyle etiology. A delayed treatment that is inadequate and when administered too late its pre-disposes the affected individual to the complications of diabetes. However, Streptozotocin is an agent that is frequently used to induce diabetes mellitus in albino rats [58,59]. It is generally accepted that the cytotoxicity produced by streptozotocin affects the DNA alkylation and subsequent activation of poly(ADP-ribose) synthetase. This causes rapid and dangerous depletion of NAD in pancreatic islets [60,61]. It was also reported that the free radicals may play an essential role in the mechanism of $\beta$-cell damage and effect of streptozotocin induced-diabetes [62], thus the presence of antioxidant at $36.55 \mu \mathrm{g} / \mathrm{mL}$ [63].

The progression of T2Diabetes begins with an impairment of glucose tolerance $[64,65]$ and is often associated with a state of insulin resistance. Renal histopathologic observational data were described in semi-quantitative descriptive and scores with a scale of 0 to 2 [66]. The mark 0 states no lesions in the organ. The mark 1 suggests hydropic degeneration, fatty degeneration, karyomegaly and pycnosis. The mark 2 states the occurrence of necrosa. Each individual score was then counted up and the mean of the group was determined for comparison with controls, then, a mild (score 0 ), moderate (score 1) and severe (score 2) lesions were identified.

The renal histopathologic observation was performed on proximal tubule nuclei as revealed in Table 5. The kidney is a target organ of insulin. Insulin binds to the insulin receptors via the nephron [67], which is essential for the proper function of the nephron, glomerulus and tubule [68]. In insulin resistance, the insulin signaling cascade in the glomerulus seems to be impaired [69]. In diabetic conditions, insulin stimulation in the transportation of proximal renal tubules is impaired so that glucose reabsorption decreases, and glucose is excreted through urine [68]. The administration of the Barringtonia racemosa extract improved the kidney and the visible cells in the proximal tubule were the same as absorbed in the normal rat (Figure 2). However, plant extract as reported by Isaac et al. [37] is said to have antioxidant potential with IC50 value of $36.55 \mu \mathrm{g} / \mathrm{mL}$, this fact suggested the ability of the extract to reduce free radical molecule which in this case may be contributed to the potential activity of this extract against T2D, as well as some result of some bioactive compound such are responsible for its antibacterial, antifungal, analgesic such as terpenes and flavonoid which has the ability to neutralize the DPPH molecule and also the properties as a free radical and a scavenger for other free radicals.

The result obtained from Figure 2 showed that the Dichloromethane extract of Barringtonia racemosa given to the diabetic rats did not cause any significant change in the histologic structure of the kidney. Thus, agreed with [70]. This suggested that administration of the Barringtonia racemosa dichloromethane Leave extract in diabetic rats did not show specific damage to proximal renal tubular cells either. Thus, the bioactive compound contained in the extract did not cause damage to the kidney organs in the tested rats when compared to the controlling agent for type 2 diabetes. 


\section{Current Research in Diabetes \& Obesity Journal}

However, the histopathologic images demonstrated that the pancreatic $\beta$-cell granulation was directly proportional to the given extract dose as shown in Table 5. The number of $\beta$-cells enhancement is significant with $\mathrm{p}<0.0001$ ) for each treatment stated that the dichloromethane extract administered to hyperglycaemic rats could improve pancreatic $\beta$-cells and depresses necrosis or apoptosis of pancreatic $\beta$-cells compared to metformin hydrochloride as shown in Figure 2. It was assumed that the modulatory effects of Barringtonia racemosa crude extract constituents on the blood glucose transporter by increasing insulin secretion, decreasing apoptosis and stimulating proliferation of pancreatic $\beta$-cells Zheng et al. [70] [71].

\section{Conclusion}

The bound flavonoids extract of $B$. racemosa kernel showed the strong antioxidant power and it displayed the type 2 anti-diabetes property. Administration of the extract with doses of 100 $\mathrm{mg} / \mathrm{kg} / \mathrm{bwt}$. and $200 \mathrm{mg} / \mathrm{kg} / \mathrm{bwt}$. orally for 14 days was not causing the histopathologic disturbance on the tested rat kidney organ.

\section{Acknowledgement}

The author Isaac John Umaru wish to appreciate Federal University of Wukari for Grant Fellowship and Universiti Malaysia Sarawak Natural Product Laboratory for their support.

\section{Author's Contribution}

Isaac John Umaru: Conceived, designed, performed the experiments and wrote the paper. Hauwa A. Umaru: Provided reagents, data analyses and experimental tools analyses. Kerenhappuch I. Umaru: Materials and analysed the data.

\section{Ethics}

This original article contains unpublished material. The corresponding author states that all of the other authors have read and agreed to the manuscript and no ethical issues are involved.

\section{References}

1. Bastaki S (2005) Diabetes mellitus and its treatment. Int J Diabetes Metab 13(3): 111-134.

2. Leahy JL, Hirsch IB, Peterson KA, Schneider D (2010) Targeting betacell function early in the course of therapy for type 2 diabetes mellitus. J Clin Endocrinol Metab 95(9): 4206-4216.

3. Rains JL, Jain SK (2011) Oxidative stress, insulin signalling and diabetes. Free Radical Biol Med 50(5): 567-575.

4. Maritim AC, Sanders RA, Watkins JB (2003) Diabetes, oxidative stress, and antioxidants: a review. J Biochem Mol Toxicol 17(1): 24-38.

5. Suryanarayana P, Saraswat M, Mrudula T, Krishna TP, Krishnaswamy $\mathrm{K}$, et al. (2005) Curcumin and turmeric delay streptozotocin-induced diabetic cataract in rats. Investigative ophthalmology \& visual science 46(6): 2092-2099.

6. Suryanarayana P, Saraswat M, Petrash JM, Reddy GB (2007) Emblica officinalis and its enriched tannoids delay streptozotocin-induced diabetic cataract in rats. Mol Vis 13: 1291-1297.

7. Suryanarayana P, Satyanarayana A, Balakrishna N, Kumar PU, Reddy GB (2007) Effect of turmeric and curcumin on oxidative stress and antioxidant enzymes in streptozotocin-induced diabetic rat. Medical Science Monitor 13(12): BR286-BR292.

8. (2011) Diabetes: Key Facts, World Health Organization, Geneva, Switzerland.

9. Shaw JE, Sicree RA, Zimmet PZ (2010) Global estimates of the prevalence of diabetes for 2010 and 2030. Diabetes research and clinical practice 87(1): 4-14.

10.Zhang S, Chai FY, Yan H, Guo Y, Harding JJ (2008) Effects of $\mathrm{N}$-acetylcysteine and glutathione ethyl ester drops on streptozotocininduced diabetic cataract in rats. Molecular Vision 14: 862-870.

11. Drel VR, Xu W, Zhang J, Pavlov IA, Shevalye H, et al. (2009) Poly (adenosine $5^{\prime}$-diphosphate-ribose) polymerase inhibition counteracts multiple manifestations of experimental type 1 diabetic nephropathy. Endocrinology 150(12): 5273-5283.

12. Siddiqui TA, Shadab Z, Nishat I, Ayasha N, Zehra Z, et al. (2003) Anticataract activity of Kohl-Chikni Dawa-a compound ophthalmic formulation of Unani medicine in alloxan-diabetic rats. Journal of ethnopharmacology 86(1): 109-112.

13. Vats V, Yadav SP, Grover JK (2004) Ethanolic extract of Ocimum sanctum leaves partially attenuates streptozotocin-induced alterations in glycogen content and carbohydrate metabolism in rats. Journal of ethnopharmacology 90(1): 155-160.

14. Preet A, Gupta BL, Siddiqui MR, Yadava PK, Baquer NZ (2005) Restoration of ultrastructural and biochemical changes in alloxaninduced diabetic rat sciatic nerve on treatment with $\mathrm{Na} 3 \mathrm{VO} 4$ and Trigonella-a promising antidiabetic agent. Molecular and cellular biochemistry 278(1-2): 21-31.

15. Welsh N, Hellerström C (1990) In vitro restoration of insulin production in islets from adult rats treated neonatally with streptozotocin. Endocrinology 126(4): 1842-1848.

16. Hemmings SJ, Spafford D (2000) Neonatal STZ model of type II diabetes mellitus in the Fischer 344 rat: characteristics and assessment of the status of the hepatic adrenergic receptors. The international journal of biochemistry \& cell biology 32(8): 905-919.

17. Farswan M, Mazumder PM, Percha V (2009) Protective effect of Cassia glauca Linn. on the serum glucose and hepatic enzymes level in streptozotocin induced NIDDM in rats. Indian journal of pharmacology 41(1): 19-22.

18. Megha Saraswat, Palla Suryanarayana, Paduru Yadagiri Reddy, Madhoosudan A Patil, Nagalla Balakrishna, et al. (2010) Antiglycating potential of Zingiber officinalis and delay of diabetic cataract in rats. Molecular vision 16: 1525-1537.

19. Schaffer SW, Wilson GL (1993) Insulin resistance and mechanical dysfunction in hearts of Wistar rats with streptozotocin-induced noninsulin-dependent diabetes mellitus. Diabetologia 36(3): 195-199.

20. Takada J, Machado MA, Peres SB, Brito LC, Borges-Silva CN, et al. (2007) Neonatal streptozotocin-induced diabetes mellitus: a model of insulin resistance associated with loss of adipose mass. Metabolism 56(7): 977-984.

21. Anwer T, Sharma M, Pillai KK, Iqbal M (2008) Effect of Withania somnifera on Insulin Sensitivity in Non-Insulin-Dependent Diabetes Mellitus Rats. Basic \& clinical pharmacology \& toxicology 102(6): 498503.

22. Abdollahi M, Zuki AB, Goh YM, Rezaeizadeh A, Noordin MM (2011) Effects of Momordica charantia on pancreatic histopathological changes associated with streptozotocin-induced diabetes in neonatal rats. Histology and Histopathology 26(1): 13-21.

23. Movassat J, Portha B (2007) Early administration of keratinocyte growth factor improves $\beta$-cell regeneration in rat with streptozotocininduced diabetes. Journal of Endocrinology 195(2): 333-340. 


\section{Current Research in Diabetes \& Obesity Journal}

24. Portha B, Levacher C, Picon L, Rosselin G (1974) Diabetogenic effect of streptozotocin in the rat during the perinatal period. Diabetes 23(11): 889-895.

25. Weir GC, Clore ET, Zmachinski CJ, Bonner-Weir S (1981) Islet secretion in a new experimental model for non-insulin-dependent diabetes. Diabetes 30(7): 590-595.

26. Iwase M, Kikuchi M, Nunoi K, Wakisaka M, Maki Y, et al. (1986) A new model of type 2 (non-insulin-dependent) diabetes mellitus in spontaneously hypertensive rats: diabetes induced by neonatal streptozotocin treatment. Diabetologia 29(11): 808-811.

27. V Grill, M Westberg, CG Ostenson (1987) B cell insensitivity in a rat model of non-insulin-dependent diabetes. Evidence for a rapidly reversible effect of previous hyperglycemia. The Journal of clinical investigation 80(3): 664-669.

28. Kim JO, Lee GD, Kwon JH, Kim KS (2009) Anti-diabetic effects of new herbal formula in neonatally streptozotocin-induced diabetic rats. Biological and Pharmaceutical Bulletin 32(3): 421-426.

29. Pari L, Ashokkumar N (2005) Effect of N-benzoyl-d-phenylalanine on lipid profile in liver of neonatal streptozotocin diabetic rats. Fundamental \& clinical pharmacology 19(5): 563-568.

30. Suryanarayana P, Krishnaswamy K, Reddy GB (2003) Effect of curcumin on galactose-induced cataractogenesis in rats. Mol Vis 9(9): 223-230.

31. Song P, Wu Y, Xu J, Xie Z, Dong Y, et al. (2007) Reactive nitrogen species induced by hyperglycemia suppresses Akt signaling and triggers apoptosis by upregulating phosphatase PTEN (phosphatase and tensin homologue deleted on chromosome 10) in an LKB1-dependent manner. Circulation 116(14): 1585-1595.

32. Zimmet P, Thomas CR (2003) Genotype, obesity and cardiovascular disease-has technical and social advancement outstripped evolution? Journal of internal medicine 254(2): 114-125.

33. Khan S, Jabbar A, Hasan CM, Rashid MA (2001) Antibacterial activity of Barringtonia racemosa. Fitoterapia 72(2): 162-164.

34. Kabir MZ, SM Rahman, MR Islam, PK Paul S Rahman (2013) A review on a mangrove species from the Sunderbans, Bangladesh: Bruguiera gymnorrhiza (L.) Lam. (Rhizophoraceae). American-Eurasian Journal of Sustainable Agriculture 7(5): 356-372.

35. Osman NI., NJ Sidik, A Awal (2015) Pharmacological activities of Barringtonia racemosa L. (Putat), a tropical medicinal plant species. J Pharm Sci Res 7(4): 185-188.

36. Lim TK (2012) Barringtonia racemosa. In: Edible Medicinal and NonMedicinal Plants, Lim TK (Edt,) Springer Science and Business Media BV, Dordrecht, Heidelberg, London and New York, pp. 114-121.

37. Isaac John Umaru, Fasihuddin Badruddin Ahmed, Hauwa A Umaru, Kerenhappuch I Umaru (2018) Barringtonia racemosa: phytochemical, pharmacological, biotechnological, botanical, traditional use and agronomical aspects. World Journal of Pharmacy and Pharmaceutical Sciences 7(8): 78-121.

38. Giesen WS, Wulfraat M Zieren, L Scholten (2007) Barringtonia Racemosa. In: Mangrove Guidebook for Southeast Asia, FAO and Wetlands International, Bangkok, Thailand and Wageningen, Netherlands.

39. Manjunath BL (1948) The Wealth of India: A Dictionary of Indian Raw Materials and Industrial Products. ( $1^{\text {st }}$ edn), Council of Scientific and Industrial Research, New Delhi, pp. 159.

40. Jayaweera DMA (1981) Medicinal plants (indigenous and exotic) used in Ceylon, part III. The National Science Council of Sri Lanka, Colombo.

41. Thomas TJ, B Panikkar, A Subramanian, MK Nair, KR Panikkar (2002) Antitumour property and toxicity of Barringtonia racemosa Roxb seed extract in mice. J Ethnopharmacol 82(2-3): 223-227.
42. Nadkarni AK (1976) Dr. KM Nadakarni's Indian Materia Medica. (3 ${ }^{\text {rd }}$ edn), Popular Prakashan Ltd, Bombay, India, pp. 177.

43. Behbahani M, AM Ali, R Muse, NB Mohammad (2007) Anti-oxidant and anti-inflammatory activities of leaves of Barringtonia racemosa. J Med Plants Res 1: 95-102.

44. Kong KW, S Mat-Junit, A Ismail, N Aminudin, A Abdul-Aziz (2014) Polyphenols in Barringtonia racemosa and their protection against oxidation of LDL, serum and haemoglobin. Food Chem 146: 85-93.

45. Sulaiman SF, KL Ooi (2014) Antioxidant and $\alpha$ - glucosidase inhibitory activities of 40 tropical juices from Malaysia and identification of phenolics from the bioactive fruit juices of Barringtonia racemosa and Phyllanthus acidus. J Agric Food Chem 62(39): 9576-9585.

46. Mmushi TJ, P Masoko, LK Mdee, MP Mokgotho, LJ Mampuru, et al. (2010) Anti-mycobacterial evaluation of fifteen medicinal plants in South Africa. Afr J Tradit Complement Altern Med 7(1): 34-39.

47. Saha S, KK Sarkar, ML Hossain, A Hossin, AK Barman (2013) Bioactivity studies on Barringtonia racemosa (lam.) Bark. Pharmacol Online 1: 93100 .

48. Hussin NM, R Muse, S Ahmad, J Ramli, M Mahmood (2009) Antifungal activity of extracts and phenolic compounds from Barringtonia racemosa L. (Lecythidaceae). Afr J Biotechnol 8: 2835-2842.

49. Sikha P, PG Latha, SR Suja GI Anuja, S Shyamal (2010) Anti-inflammatory and analgesic activity of Barringtonia racemosa Roxb. Fruits. Ind J Nat Prod Resour 1: 356-361.

50. Patil KR, CR Patil, RB Jadhav, VK Mahajan, P Raosaheb (2011) Antiarthritic activity of bartogenic acid isolated from fruits of Barringtonia racemosa Roxb. (Lecythidaceae). Evidence-Based Complementary Alternative Med 1-7.

51. Gowri PM, AK Tiwari, AZ Ali, JM Rao (2007) Inhibition of $\alpha$-glucosidase and amylase by bartogenic acid isolated from Barringtonia racemosa Robx. seeds. Phytotherapy Res 21(8): 796-799.

52. Ponnapalli MG, S Sukki, SCVAR Annam, M Ankireddy, H Tirunagari, et al. (2015) $\alpha$-Glucosidase inhibitory monoacylated polyhydroxytriterpenoids from the fruits of Barringtonia racemosa Tetrahedron Lett 56(12): 1570-1574.

53. Deraniyagala SA, WD Ratnasooriya, CL Goonasekera (2003) Antinociceptive effect and toxicological study of the aqueous bark extract of Barringtonia racemosa on rats. J Ethnopharmacol 86(1): 2126.

54. Isaac John Umaru, Fasihuddin A Badruddin, Zaini B Assim, Hauwa A Umaru (2018) Cytotoxicity (Brine shrimp Lethality Bioassay) of Barringtonia racemosa Leaves, Stem-Bark and Root Extract. Journal of Biotechnology and Bioengineering 2(2): 1-6.

55. Fasihuddin BA, Sallehuddin NKNM, Assim Z (2010) Chemical constituents and antiviral study of Goniothalamus velutinus. Malaysian Journal of Fundamental and Applied Sciences 6(1): 73-76.

56. Arul B, R Kothai, AJM Christina (2006) Antihyperglycemic and hypoglycemic effect of Bougainvillea spectabilis Linn. In normal and glucose induced diabetic rats. Hamdard Med 49: 18-21.

57. Candasamy M, TEGK Murthy, KS Gubiyappa, DK Chellappan, G Gupta (2014) Alteration of glucose lowering effect of glibenclamide on single and multiple treatments with fenofibrate in experimental rats and rabbit models. J Basic Clin Pharmacy 5(3): 62-67.

58. Spitalnik PF (2016) Histology laboratory manual 2016-2017. College of Physicians and Surgeons, Columbia University, New York.

59. Szkudelski T (2001) The mechanism of alloxan and streptozotocin action in $\beta$-cells of the rat pancreas. Physiol Res 50(6): 537-546. 


\section{Current Research in Diabetes \& Obesity Journal}

60. Yamagishi N, Nakayama K, Wakatsuki T, Hatayama T (2001) Characteristic changes of stress protein expression in streptozotocin induced diabetic rats. Life Sci 9(22): 2603-2609.

61. Bennet RA, Pegg AE (1981) Alkylation of DNA in rat tissues following administration of streptozotocin. Cancer Res 41: 2786-2790.

62. Horita S, Nakamura M, Suzuki M, Satoh N, Suzuki A, et al. (2017) The role of renal proximal tubule transport in the regulation of blood pressure. Kidney Res Clin Pract 36(1): 12-21.

63. Bolzan AD, Bianchi MS (2002) Genotoxicity of streptozotocin. Mutat Res 512(2-3): 121-134

64. Ohkuwa T, Sato Y, Naoi M (1995) Hydroxyl radical formation in diabetic rat induced by streptozotocin. Life Sci 56(21): 1789-1798.

65. Suhita NL, IW Sudira, IBO Winaya (2013) Histopathological kidney of rat white the effect of the pegagan (Centella asiatica) extract against peroral. Buletin Veteriner Udayana 5: 71-78.

66. Nakamura R, Emmanouel DS, Katz AI (1983) Insulin binding sites in various segments of the rabbit nephron. J Clin Invest 72(1): 388-392.
67. Hale LJ, Coward RJ (2013) The insulin receptor and the kidney. Curr Opin Nephrol Hypertens 22(1): 100-106.

68. Lay A, Coward RJ (2013) Recent advances in our understanding of insulin signalling to the podocyte. Nephrology Dialysis Transplantation 29(6): 1127-1133.

69. Khoshnoud S, HM Kouchesfahani, M Nabiuni (2017) Evaluation of the protective effect of hydroalcoholic extract of raspberry fruit on aquaporin 1 expression in rats' kidney treated by methotrexate. Cell J 19(2): 306-313.

70. Zheng S, Zhao M, Wu Y, Wang Z, Ren Y (2016) Suppression of pancreatic beta cell apoptosis by Danzhi Jiangtang capsule contributes to the attenuation of type 1 diabetes in rats. BMC Complement Altern Med 16: 31-41.

71. (2015) Classification and diagnosis of diabetes. ADA, Diabetes Care 38(8-16): 58-516

Your next submission with Juniper Publishers
will reach you the below assets
- Quality Editorial service
- Swift Peer Review
- Reprints availability
- E-prints Service
- Manuscript Podcast for convenient understanding
- Global attainment for your research
- Manuscript accessibility in different formats
( Pdf, E-pub, Full Text, Audio)
- Unceasing customer service
Track the below URL for one-step submission
https://juniperpublishers.com/online-submission.php

